JOURNAL Of CONTEMPORARY INDONESIAN ART

Jurusan Seni Murni

FSR ISI Yogyakarta

ISSN: 2442-3394

E-ISSN: 2442-3637

\title{
HUBUNGAN PERSONAL BRANDING PERUPA DENGAN ARTIST MERCHANDISE DALAM PROSES BERKARYA
}

\author{
Oleh: Ifthinan Juanitasari
}

Institusi: Institut Seni Indonesia Yogyakarta

Email: thinanjs@gmail.com

\section{ABSTRAK}

Penelitian yang berjudul Hubungan Personal Branding Perupa Dengan Artist Merchandise Dalam Proses Berkarya bertujuan untuk mengetahui: (1) pemahaman personal branding perupa di Yogyakarta, (2) keterkaitan personal branding dalam pengelolaan artist merchandise, (3) karya perupa diapresiasi dalam bentuk artist merchandise, serta personal branding yang baru-baru ini dilakukan seniman lewat media sosial. Berbicara tentang seniman hari ini, tidak hanya bekerja sebagai pembuat produk dan memproduksinya, tetapi juga menjual dirinya. Hal ini disebut juga personal branding, personal branding merupakan proses pembentukan kesan (image) yang ditetapkan dalam pikiran orang lain tentang individu kelompok atau organisasi. Artist merchandise juga berperan dalam usaha personal branding seniman, karena image karyanya dapat diaplikasikan pada media lain. Penelitian ini dikategorikan sebagai penelitian deskriptif kualitatif, dimana penelitian ini berupa wawancara dan observasi langsung ke seniman dan media sosialnya. Populasi dalam penelitian ini adalah perupa yang berdomisili di Yogyakarta yang aktif berpameran dan membuat karyanya pada media lain selain media konvensional dengan berkolaborasi dengan brand lain, serta dua seniman yang memutuskan berkarya bersama pada media konvensional maupun non konvensional atau yang disebut dengan duo artist, yaitu Ronald Apriyan dan juga Rara Kuastra (Tempa). Hal tersebut diteliti untuk memberikan gambaran bahwa artist merchandise di Yogyakarta banyak digemari.

Kata kunci: Profesi Seniman, Personal Branding, Artist Merchandise

\begin{abstract}
Research entitled the Relationship of the Artist's Personal Branding and Artist Merchandise in the Work Process is to know: (1) The understanding of painters' personal branding in Yogyakarta, (2) The relationship of personal branding and managing artist merchandise, (3) Painters' works appreciated in artist merchandise which is done recently by sosial media. Talking about artists nowdays, who not only work as products maker and produce them, but also sell themseles. It is called personal branding, personal branding is process in performing image set in others mind of group of individu or organization. Artist merchandise also seres in artist personal branding effort, since the image of their works can be applied in other media. This research is categorised as descriptive qualitative research, in wich done in interview and observation directly to the artist and social media. The population in this research are visual artist who live in Yogyakarta, who are active in holding exhibition and making works for media than conventional media collaborated with other brands. There are two visual artist who have decided to work in conventional media and non media called as Duo artist, the are Rara Kuastra (Tempa-duo artist Rara and Putu) and Ronald Apriyan. It is researched to give image that artist merchandise in Yogyakarta is fonded a lot. Key words: Artist Profession, Personal Branding, Artist Merchandise
\end{abstract}




\section{A. Latar Belakang}

Selama ini pekerjaan sebagai seniman adalah pekerjaan yang masuk kategori wirausaha. Pengertian wirausaha secara umum adalah seorang yang berani berusaha secara mandiri dengan mengerahkan segala sumber daya dan upaya meliputi kepandaian mengenali produk baru, menentukan cara produksi baru, menyusun operasi untuk menciptakan sebuah peluang usaha, pengadaan produk baru, memasarkannya, serta mengatur permodalan operasinya untuk menghasilkan sesuatu yang bernilai lebih tinggi, dengan segala resiko yang akan dihadapinya ( www.zonareferensi.com/ pengertian-wirausaha/, akses 18 Desember 2019, 12.18 WIB). Sebagai wirausahawan berarti apapun yang ia kerjakan adalah yang dikerjakannya sendiri, tidak ada yang mengatur pekerjaannya selain dirinya sendiri. Untuk menghasilkan karya yang baik, seniman pasti akan mengaturnya sendiri, karena tidak ada seseorang yang akan mengaturnya seperti halnya bos atau pimpinan perusahaan.

Seniman dapat didefinisikan sebagai nama profesi seseorang dalam melakukan kegiatan kerja yang menciptakan karya seni di bidang seni rupa murni. Profesi hendaknya dilakukan secara profesional, yaitu dengan mengandalkan suatu keahlian yang tinggi dengan baik. Menggeluti pekerjaan secara profesional pasti diinginkan semua orang di bidang apa saja yang mereka pilih, termasuk pekerjaan di bidang seni. Saat ini seniman rupa sudah dapat dijadikan sebagai profesi yang dapat memberi penghasilan yang tidak sedikit. Seorang seniman sama seperti profesi lainnya, semakin ditekuni semakin bisa dijadikan pekerjaan. (Hartanto, 2018)

Seniman dapat diartikan sebagai profesi yang berfokus dalam proses kreativitas, yaitu proses antara persepsi memori dan persepsi luar. Dalam hal ini, seorang seniman memiliki kemampuan dalam mengembangkan dan memperkaya ide gagasan inovatif, ini dilakukan melalui proses interaksi dari pengalaman yang diendapkan melalui memori kemudian memadu persepsi yang didapat dari lingkungan dalam proses penciptaan karya seni. Berbicara tentang seniman hari ini, tidak hanya bekerja sebagai pembuat produk dan memproduksinya, tetapi juga menjual dirinya.

Seniman didorong oleh rasa takjub dan ingin tahu mereka. Rangsangan kreatif seringkali terkekang jika seseorang takut untuk membuat kesalahan. Seniman menunjukkan keberanian untuk mengambil resiko. Mereka mampu untuk melihat sekeliling mereka dalam waktu yang lama untuk mencapai tujuan mereka (Marianto, 2010:10)

Saat ini, seniman dapat memperkenalkan diri dan karyanya secara intens salah satunya lewat media sosial. Saat ini media sosial yang paling gencar adalah Instagram. Salah satu akun Instagram yang digunakan sebagai ajang untuk memperkenalkan diri dan karya adalah@_tempa_yang dijalankan oleh Rara Kuastra dan Putut Utama. Mereka banyak dikenal oleh masyarakat dan bebas memamerkan karya yang mereka hasilkan lewat media sosial Instagramnya tersebut. Masyarakat secara tidak sadar akan mengenali Putut dan Rara lewat media sosial Tempa. Selain menggunakan media sosial Instagram untuk menunjang eksistensinya, seniman juga membuat karya seni dalam bentuk media lain yang disebut dengan artist merchandise.

Artist merchandise dimaksud juga sebagai kreasi seniman untuk mengaplikasikan karya seni di luar media konvensional, lalu muncul pertanyaan apakah karya murni, artist merchandise, dan personal branding saling berhubungan dalam proses berkarya dan eksistensi seniman tersebut di masa kontemporer saat ini. Hal tersebut menjadi sebuah wacana kritis yang bertujuan sebagai jawaban hubungan antara pengaruh pemikiran kritis dan wacana yang ada. Artist merchandise merupakan kategori yang kerap luput dari jangkauan cita rasa seni, itu karena penggunaan istilah merchandise acapkali merujuk pada produk-produk yang diperjual belikan untuk kepentingan 
promosi.

Saat ini seniman mulai berlombalomba untuk berkarya melalui medium lain, salah satunya artist merchandise, dimana karya tersebut dapat digunakan untuk kegiatan sehari-hari. Selain itu, hal ini juga bermanfaat untuk branding karya seni seorang perupa ataupun studio seni itu sendiri (http://www.mldspot.com/, akses 4 Oktober 2019 pukul 07.50 WIB). Upaya ini adalah salah satu kesadaran seniman akan personal branding tersebut.

Di Yogyakarta, Seniman memilih media lain yang fungsional sudah dilakukan Eddie Hara pada sekitar tahun 2000 an. Jaran T-Shirt pernah memproduksi kaos yang mengambil image dari karya-karya Eddie Hara. Image yang diambil bagian dari karya bukan secara khusus image dibuat untuk diaplikasikan pada kaos. Karya yang disematkan pada produk itu ternyata bukan hal baru dan itu juga semakin marak ketika merek besar dalam dunia fashion Louis Vuitton, Chanel, dan Prada melakukannya.

\section{B. Rumusan Masalah}

Setelah mengetahui latar belakang masalah, terdapat tiga rumusan masalah yang akan dibahas dalam penelitian ini, yaitu:

1. Bagaimana karya perupa diapresiasi dalam bentuk artist merchandise?

\section{Tujuan Penelitian}

Mengacu pada rumusan permasalahan, maka penelitian ini bertujuan untuk :

1. Mengetahui cara seniman rupa Yogyakarta melakukan branding dirinya dengan media sosial dan non media sosial.

2. Mengetahui bagaimana apresiasi penggemar terhadap karya konvensionalnya dan juga karya artist merchandise yang terjadi di era seni rupa kontemporer saat ini.

\section{Manfaat Penelitian}

1. Hasil penelitian ini diharapkan dapat bermanfaat menambah sumbangan pemikiran dan informasi, serta pengalaman dan pengetahuan bagi peneliti yang ingin meneliti permasalahan sejenis bagi pengembangan pengetahuan serta menjadi salah satu referensi untuk kajian lebih mendalam, khususnya terhadap fenomenafenomena seni rupa yang terjadi.

\section{E. Batasan Penelitian}

Pada penelitian ini penulis melakukan batasan masalah agar analisis lebih jelas dan mendalam. Subjek dalam penelitian ini adalah seniman yang aktif berpameran, mempunyai karya diluar media konvensional yang disebut dengan artist merchandise serta menggunakan media sosial Instagram untuk karirnya. Sehingga penelitian ini akan fokus pada tujuan seniman berkarya, melakukan branding diri, serta membuat artist merchandise. Sehingga penelitian ini membatasi pada beberapa hal tersebut, yang mungkin menghasilkan hasil yang berbeda jika pembahasan dan metode ini tidak menggunakan seniman tersebut pada studi kasus penelitian ini.

\section{F. Metode Penelitian}

Penelitian yang akan dilakukan adalah penelitian kualitatif. Metode kualitatif merupakan metode penelitian yang digunakan untuk meneliti pada kondisi objek yang alamiah, (sebagai lawannya adalah eksperimen karena mendapatkan perlakuan)(Ratna, 2010).

$\mathrm{P}$ enelitian dengan judul Hubungan Personal Branding Dengan Artist Merchandise Dalam Proses Berkarya, menggunakan pendekatan kualitatifdeskriptif. Hal ini didasari pada pertimbangan bahwa peneliti ingin memahami, mengkaji secara mendalam, serta memaparkan dalam tulisan ini, perihal personal branding dan artist merchandise perupa.

Metode deskriptif tidaklebih daripada penelitian yang bersifat penemuan faktafakta seadanya. Penemuan gejala-gejala itu berarti juga tidak sekedar menunjukkan distribusinya, akan tetapi termasuk usaha mengemukakan hubungannya satu dengan yang lain dalam aspek-aspek yang diselidiki. Secara singkat dapat dikatakan bahwa metode deskriptif merupakan 
langkah-langkah melakukan representasi obyektif tentang gejala-gejala yang terdapat didalam hubungan personal branding perupa dengan bantuan artist merchandise dalam profesionalitas kerjanya.

\section{Populasi Dan Sampling}

Populasi dalam penelitian ini adalah perupa yang berdomisili di Yogyakarta, aktif berpameran dan membuat karyanya pada media lain selain media konvensional serta aktif memperlihatkan aktivitas proses berkeseniannya di media sosial Instagram.

Berdasarkan penjelasan tentang populasi untuk penelitian ini maka sampel dalam penelitian adalah dua seniman yang berdomisili di Yogyakarta, yaitu :

- Ronald Apriyan

- $\quad$ Rara Kuastra (TEMPA)

\section{Metode Pengumpulan Data}

Wawancara dilakukan dengan narasumber yang terlibat secara langsung. Proses pertama yaitu dengan mendatangi Rara Kuastra, kemudian dilanjutkan wawancara dengan Ronald Apriyan. Pada proses ini dilakukan pengumpulan data dengan teknik wawancara dan studi dokumentasi untuk memperoleh informasi yang dibutuhkan, alat perekam, dan buku catatan. Setelah itu mencari perbandingan hasil wawancara melalui internet dan literatur. Proses terakhir adalah pembuatan laporan penelitian.

\section{a. Metode Wawancara}

Penelitian ini menggunakan wawancara terstruktur, jenis wawancara ini termasuk dalam kategori wawancara mendalam (in dept interview) yang dalam pelaksanaannya lebih bebas bila dibandingkan dengan wawancara terstruktur. Tujuan dari wawancara ini adalah untuk menemukan permasalahan secara lebih terbuka. Wawancara akan dilakukan pada narasumber yaitu Ronald Apriyan dan Rara Kuastra.

\section{b. Metode Dokumentasi}

Pengumpulan data dengan cara mencari atau menelusuri dokumentasi yang berhubungan dengan objek penelitian. Dokumentasi terdiri dari foto yang diperoleh dari website, media sosial, serta dokumen pribadi.

\section{c. Studi Kepustakaan}

Tujuan dari studi kepustakaan adalah mengumpulkan data dengan mengkaji buku, jurnal, makalah, atau arsip yang berkaitan dengan topik penelitian. Peneliti melakukan studi kepustakaan terhadap buku-buku atau literatur tentang teori seni rupa, personal branding, branding, sosial media yang berkaitan dengan penelitian hingga manajemen seni rupa untuk menghimpun informasi sebagai referensi dalam penulisan penelitian.

d. Observasi

Observasi biasa diartikan sebagai pengamatan dan per catatan secara sistematik terhadap gejala yang tampak pada obyek penelitian. Observasi langsung dilakukan terhadap obyek di tempat terjadinya peristiwa, sehingga obsever berada bersama obyek yang diselidikinya. (Nawawi, 1995)

Selain wawancara dengan narasumber yang bersangkutan, akan dilakukan pencarian data (observasi) meliputi kegiatan seniman, karya seniman, kegiatan pameran yang diadakan dan diikuti, serta artist merchandise yang dibuat oleh seniman tersebut melalui media sosial Instagram dan juga artikel-artikel terkait perupa yang diteliti lewat media pencarian Google. Sehingga data observasi tersebut dapat memperkuat data penelitian.

\section{Metode Analisis Data}

Analisis data adalah tahapan selanjutnya. Setelah data wawancara, dokumentasi maupun hasil studi pustaka terkumpul, langkah selanjutnya adalah mengklarifikasi dan memilah data untuk disajikan. Semua data yang didapatkan dari penelitian akan dipaparkan secara deskriptif, kemudian dianalisis menggunakan teori-teori dan literatur yang berhubungan dengan pembahasan penelitian. Bagaimana pada akhirnya personal branding dan manajemen 
artist merchandise akan dianalisis dan literatur terkait dengan teori seni rupa.

\section{TINJAUAN PUSTAKA DAN LANDASAN TEORI}

\section{A. Tinjauan Pustaka}

Tinjauan pustaka pada penelitian ini digunakan untuk membandingkan literatur yang didapat dari teori-teori yang ada dan dengan hasil wawancara yang telah dilakukan. Dalam tinjauan pustaka penelitian ini, teori yang sudah ada dan hasil wawancara dibandingkan dengan jurnal-jurnal atau penelitian yang sudah dibuat sebelumnya oleh penulis lain.

Pada ranah akademis, posisi seorang seniman tentunya perlu diperjelas agar diketahui seberapa besar pencapaiannya pada ranah seni rupa nasional maupun global. Faktor-faktor apa saja atau siapa yang dapat memberikan penilaian pada seorang seniman agar dapat diakui oleh masyarakat luas. Profesi dan profesional saling berkaitan. Seseorang yang memiliki profesi atau pekerjaan harus mempunyai rasa profesional yang tinggi, agar apa yang dikerjakan dapat diselesaikan dengan baik dan hasilnya berguna bagi orang lain.

Gisela Anindita Pasca Sarjana ISI Yogyakarta dalam tesisnya tahun 2018, membahas profesi seniman lebih kepada project artists khususnya Eko Nugroho dan kolektor atau sponsor untuk berkesenian. Dalam tesis Anindita (Tesis, 2018:12), klasifikasi seniman secara global berdasarkan Resch :

1. Superstar Artist

2. Mature / Emerging and Successful

Artist

High Street Artist

Vanity Artist

Poor Dogs Artist

Seniman sebagai brand, beberapa penelitian akhirnya menarik seniman menjadi sebuah brand akan dirinya sendiri dan melakukan marketing berdasarkan tata cara ilmu branding. Schroeder (2005, 2009) dan Vilpponen (2009) mengatakan bahwa strategi marketing karya seni dapat mengadaptasi strategi pemasaran sebuah brand dengan menjadikan seniman itu sendiri sebagai brand. Maka proyekproyek yang dibuat akan memiliki objektif berdasarkan value, visi misi, hingga karakteristik sang seniman (Anindita, Tesis, 2018:19).

Reputasi seniman juga dapat mempengaruhi proses berkeseniannya. Semakin tinggi reputasi seorang seniman, maka kepercayaan para penggemar maupun kolektor akan semakin besar.

Dalam dunia seni rupa, apresiasi dari masyarakat sangat dibutuhkan untuk meningkatkan eksistensinya. Begitu juga seniman. Melalui sebuah media yang menarik di kalangan masyarakat, komunikasi massa yang diciptakan seorang seniman akan mendapat banyak respon berupa apresiasi. Pada kajian personal branding di media sosial, penulis membandingkan dengan Laporan Tugas Akhir Pengkajian S1 Mirrah Fitriana Maghfiroh pada tahun 2017.

Menurut Maghfiroh dalam skripsinya, media adalah sarana penyampaian termasuk di dalamnya adalah media penyiaran, media cetak, surat langsung, iklan outdoor dan media pendukung lainnya. Media dapat berupa media konvensional seperti radio, TV, billboard, poster, koran dan majalah tetapi juga dapat berupa media online seperti internet. Media online yaitu, media baru (internet) dan media sosial (produk kemunculan media baru).

\section{B. Landasan Teori}

Landasan teori ini digunakan sebagai penguat beberapa tinjauan pustaka yang telah diperoleh serta menjadi landasan temuan-temuan hasil wawancara serta observasi dari narasumber penelitian.

\section{Seniman (Artist)}

Seniman didefinisikan sebagai kreator yang secara intesif mengisi kehidupannya dengan penciptaan objek estetis. Dalam berkesenian, seniman bekerjasama atau paling tidak bersentuhan dengan infrastruktur kesenian atau pihak 
yang mendukung profesinya. Di sini, istilah seniman digunakan dalam lingkup luas.

Pada dekade 1980-an, di Indonesia muncul istilah perupa. Kata ini untuk menamai seniman di dunia seni rupa kontemporer. Namun demikian, pada perkembangannya istilah perupa digunakan secara umum untuk para seniman dalam bidang seni rupa meskipun mereka hanya menciptakan satu jenis karya seperti lukisan, grafis, patung, desain, atau kriya, asalkan mereka masih sezaman dengan kritikus atau kurator yang menulisnya.

Seniman sering diidentikkan sebagai pribadi yang kreatif, meskipun pribadi kreatif bukan hanya monopoli seniman. Selanjutnya, menurut Abraham Maslow, pribadikreatifmemilikicirifleksibel, spontan, berani, dan terbuka (Junaedi, 2017:120128). Seniman dapat didefinisikan sebagai nama profesi seseorang dalam melakukan kegiatan proses-proses penciptaan karya seni dibidang seni murni. Seniman dapat diartikan sebagai manusia yang mengalami prose kreativitas, yaitu proses interaksi antara presepsi memori dan persepsi luar (Santo, dkk., 2012: 91).

Pada dasarnya seniman adalah seorang spesialis, artinya seorang yang memiliki kekhususan, yaitu kekhususan dalam hal memiliki daya dan kemampuan mencipta seni atau menghasilkan seni. Sedangkan seni adalah hasil karya cipta manusia yang istimewa nilainya. Seniman adalahorangyangmemiliki daya tanggapdan daya ungkap lebih tinggi daripada manusia yang bukan seniman. seniman adalah manusia yang memiliki sifat-sifat istimewa yang diperoleh sebagai anugrah dari Tuhan Yang Maha Esa. Kelebihan seniman dalam daya tanggap terhadap sesuatu karena seniman memiliki ketajaman mengamati suatu objek sampai pada bagian yang sekecil-kecilnya, yang renik-renik, bahkan kemampuan mengamati itu tidak terbatas pada wujud yang kasat mata, melainkan juga yang menjadi latar belakang objek yang berwujud itu (Bastomi, 1992: 98).

Pandangan atau pemikiran seniman yang sebenarnya bersifat subjektif itu pada akhirnya berada dalam suatu proses perkembangan jiwa untuk mencapai keadaan yang sadar, sementara karya seni adalah perwujudan berbagai nilai seni yang mengarah pada pemahaman nilai mutlak di luar jiwa subjektif seniman. Pengertian semacam itu, tentu tidak berarti bahwa tiap karya seni dengan sendirinya adalah suatu kebenaran, atau dianggap bernilai pasti karena mewakili nilai kebenaran tertentu.

Beberapa brand fashion yang sudah memiliki ciri khas produk sendiri pun akhirnya tertarik untuk berkolaborasi dengan seniman yang akhirnya menghasilkan produk artist merchandise,yaitu Louis Vouitton, Dior, Chanel, dan Cotton Ink.

Brand fashion dalam negeri maupun luar negeri yang berkolaborasi dengan banyak seniman besar di seluruh dunia, menjadikan karya-karya Iartist merchandise tersebut sebagai promosi serta memperkaya koleksi mereka.

Art merchandise adalah promosi penjualan barang dagangan yang diproduksi secara sadar dengan cara yang mempengaruhi rasa keindahan dengan mengkoordinasi produksi, pemasaran, strategi iklan, tampilan dan penjualan. Atau dengan bahasa yang lebih mudahnya: Bikin produk seni dalam bentuk barang yang bisa dipakai, dibeli, orang banyak (https: / / kopikeliling.com/, akses 5 April 2019, 19.25 WIB).

Artist Merchandising di sini merupakan produk massal, turunan atau pengembangan dari karya dari seniman yang memiliki fungsi dan nilai berbeda seperti karya seni. Misalnya fungsi pakai, nilai ini berkaitan dengan nilai dalam seni, yang kemudian dipasarkan dalam dunia seni rupa ataupun penjualan langsung pada khalayak umum. Artist merchandise adalah perkembangan dari karya yang sudah ada atau pertama (original artwork) secara visual atau turunan dari karya itu dijadikan produk pakai diterapkan dalam produk-produk yang bisa dipakai.

\section{Media Sosial}

Pengertian media terkadang cenderung lebih dekat terhadap sifatnya 
yang massa karena terlihat dari berbagai teori yang muncul dalam komunikasi massa. Namun, semua definisi mempunyai kecenderungan yang sama saat disebut apa itu media, yang muncul adalah sarana disertai dengan teknologinya. Media sosial merupakan salah satu produk dari kemunculan teknologi baru. Di dalam media sosial individu maupun kelompok saling berinteraksi secara online melalui jaringan internet. Semenjak kemunculannya, media sosial tidak hanya digunakan oleh individu tetapi juga mulai digunakan oleh organisasi atau perusahaan besar maupun kecil untuk melakukan komunikasi dengan publiknya.Social networking atau jaringan sosial merupakan medium yang paling popular dalam kategori media sosial. Karakter utama dari situs jejaring sosial adalah setiap pengguna yang sudah diketahuinya dan kemungkinan sering bertemu di dunia nyata (offline) maupun membentuk jaringan pertemanan baru.

Dalam banyak kasus, pembentukan pertemanan baru ini berdasarkan pada sesuatu yang sama, misalnya hobi atau kegemaran, sudut pandang politik, asal sekolah atau universitas, atau profesi pekerjaan. (Nasrullah, 2017)

\section{B.7 Hubungan Artist Merchandise di Era Global}

Takashi Murakami adalah seniman kontemporer yang terkenal dengan konsep paduan seni dan produk pakai. Berawal dari karya lukisan tradisional Jepang, scifi, anime, dan pasar seni global, perupa Takashi Murakami menciptakan lukisan, patung, dan film yang dipopulerkan dengan motif berulang yang memiliki karakter dari kreasinya sendiri. Karya-karyanya yang luas menghasilkan persimpangan sejarah, budaya pop, dan seni rupa.

Murakami menciptakan istilah "superflat", yang menggambarkan karakteristik estetika tradisi artistik Jepang dan sifat budaya serta masyarakat Jepang pasca-perang Jepang. Superflat juga digunakan sebagai istilah untuk menggambarkan gaya artistik Murakami dan seniman Jepang lainnya yang telah ia pengaruhi (https://gagosian.com/artists/ takashi-murakami/, akses 26 November 2019, pukul 20.46 WIB.

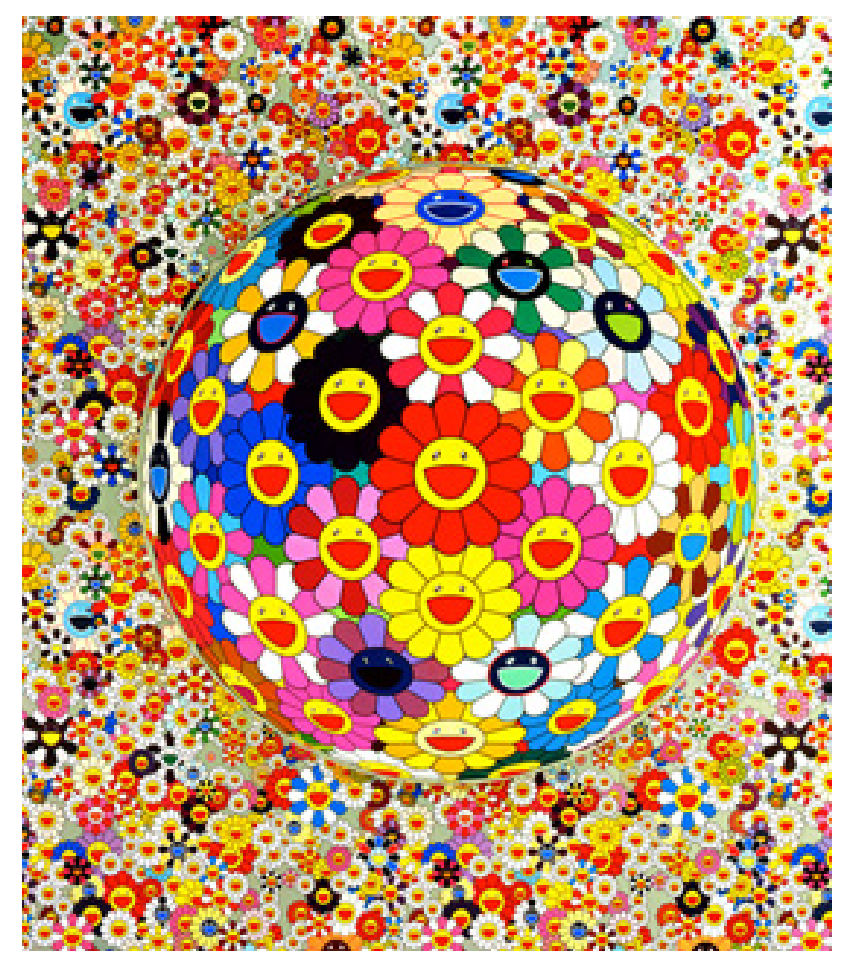

Gambar 1. Takashi Murakami, Flower ball (3D), 2002. Acrylic on Canvas Mounted on Board

(Sumber: https://www.itsliquid.com/featuredartist-takashi-murakami.html diakses 28

November 2019, pukul 21.49 WIB.)

Selain berkarya seni pada media konvensional, profesi kesenimanan Murakami meluas ke barang-barang yang diproduksi secara massal seperti mainan, gantungan kunci, dan pakaian. Pada tahun 2002, Murakami memulai kolaborasi yang berjalan selama bertahun-tahun dengan Marc Jacobs tentang pendesainan ulang monogram Louis Vuitton. Kemudian ia mengambil langkah mendasar dengan memasukkan monogram dan pola Louis Vuitton kedalam lukisan dan pahatannya.

Sementara gambarnya muncul untuk menyajikan karakter dan bentuk yang belum pernah terjadi sebelumnya, banyak yang berisi referensi sejarah seni yang tidak berbelit-belit. Beberapa bahkan melakukan pembaruan kontemporer pada 
karya-karya tradisional Jepang. Ia tidak hanya menggabungkan periode waktu yang berbeda, gaya, dan materi pelajaran dalam karyanya. Pendekatannya terhadap seni juga melintasi batas antara galeri, studio, pameran seni, ataupun media. Membuat lukisan dan patung, menjadikan beliau tuan rumah pameran seni bagi seniman pendatang, pameran yang dikuratori, dan membuat film yang menampilkan banyak karakter dan motifnya. Murakami menggabungkan fantasi, sains, dan sejarah. Beliau menunjukkan bahwa semua kategori bisa menjadi satu.

Kolaborasinya dengan banyak brand ternama membuat karir Takashi Murakami semakin melambung. Brand yang berkolaborasi dengannya antara lain adalah Louis Vuitton, Chanel, Garage MCA, dan masih banyak lagi, bahkan beberapa waktu lalu beliau berkolaborasi dengan musisi Billie Eilish. Takashi Murakami dan Billie membuat projek video klip sampai dengan merchandise.

Takashi Murakami seorang seniman Jepang yang sudah mengawali karir sebagai seniman lukis. Setelah Namanya melambung, Murakami akhirnya membuat karya artist merchandise agar penggemar lainnya dapat memperoleh karya seninya dengan mudah dalam bentuk media yang dapat digunakan sehari-hari. Murakami juga telah berkolaborasi dengan brand terkenal dunia. Yang paling terkenal adalah karya artist merchandise kolaborasinya dengan Louis Vuitton.

Karya artist merchandise sudah lama diminati oleh seniman, dilihat dari Takashi Murakami yang aktif berkarya dan berkolaborasi dengan banyak brand terkenal. Dipilihnya Takashi Murakami dalam pembahasan penelitian ini untuk membuat perbandingan artist merchandise yang ada di luar negeri sebagai rujukan untuk membaca perkembangannya di Indonesia saat ini.

Dari wawancara dengan Ronald Apriyan dan Rara Kuastra didapatkan , bahwa media sosial menjadi catatan penting untuk seniman hari ini. Penggemar dapat dengan mudah melihataktifitas apa saja yang dilakukan oleh seniman yang mereka senangi. Bahkan, penggemar bisa tertarik dengan karya yang dibuat dari media sosial tersebut. Dari observasi yang diperoleh selama ini, bahwa Ronald dan Rara sangat aktif mengunggah potret aktifitasnya pada media sosial Instagram, karena seperti wawancara diatas, mereka sudah menyadari bahwa personal branding itu sangat penting dalam penunjang proses berkarya.

Dalam observasi melalui Instagram diatas, digambarkan diagram perhitungan like dan comment tertinggi selama masa operasi Instagram tersebut, seperti berikut :

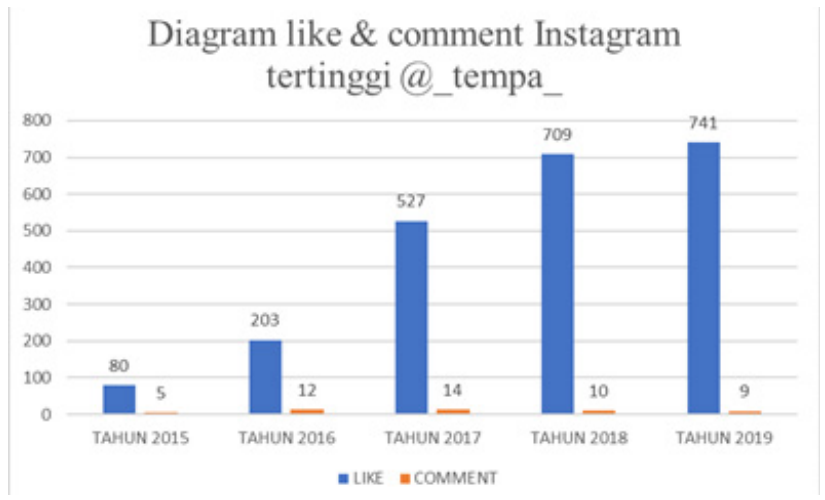

Gambar 2. Diagram like dan comment Instagram @_tempa_perhitungan tertinggi setiap tahunnya, dari tahun 2015-2019 (Sumber: Dokumen Pribadi)

Diagram tersebut adalah hasil perhitungan like dan comment Instagram Tempa milik Rara Kuastra dengan nama akun @_tempa_. Hasil tersebut dihitung dari unggahan foto pertama kali pada 14 September 2015 sampai akhir Desember 2019, dengan jumlah pengikut sebanyak 8824 dan jumlah unggahan foto dan video sebanyak 663. 


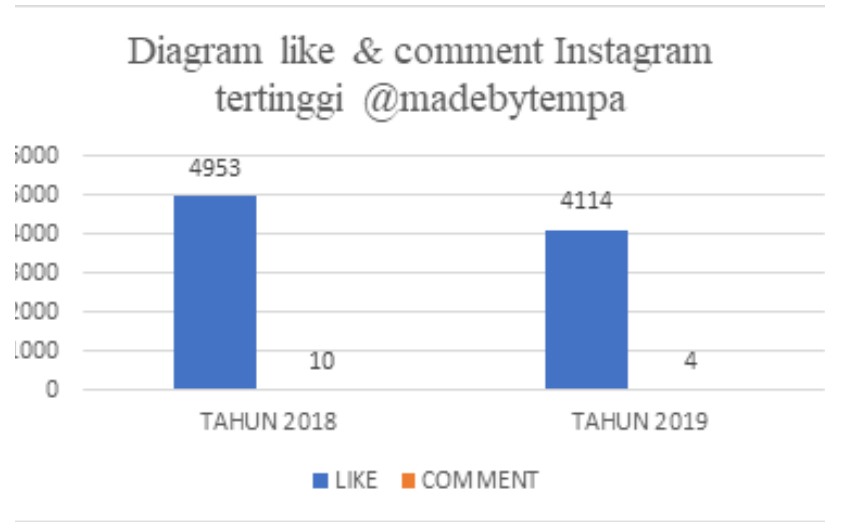

Gambar 3. Diagram like dan comment Instagram@madebytempa perhitungan tertinggi setiap tahunnya, dari tahun 20182019

Diagram tersebut adalah hasil perhitungan like dan comment Instagram Tempa milik Rara Kuastra dengan nama akun@madebytempa. Hasil tersebut dihitung dari unggahan foto pertama kali pada 9 Maret 2018 sampai akhir Desember 2019, dengan jumlah pengikut sebanyak 1707 dan jumlah unggahan foto dan video sebanyak 210 .

Dari diagram ketiga akun Instagram diatas, disimpulkan bahwa personal branding dilakukan dengan sangat baik dan hasilnya signifikan. Dapat dilihat bahwa dengan berjalannya waktu, penggemar di media sosial semakin meningkat dan seniman lebih banyak dikenal. untuk desain karya dan layout masih di kerjakan sendiri oleh Rara dan partnernya yaitu Putud.

Ronald Apriyan mengaku bahwa pengaruh marketing karya dan artist merchandise saat ini tidak 100\% berhubungan langsung. Karena keduanya berdiri pada publiknya masing-masing. Tetapi apabila karya menjadi inspirasi untuk publik mengambangkan selera mengkoleksi artist merchandise, itu lebih sering terjadi. Ini terkait pada daya kemampuan "mengkoleksi" karya yang tidak selalu "mampu". Jumlah pameran karena penjualan artist merchandise sangat meningkat. Secara jujur Ronald mengakui bahwa publikasi yang diberikan oleh artist merchandise cukup signifikan. Hal ini mendorong galeri luar dan lokal semakin sering mengundang Ronald untuk berpameran.

\section{PENUTUP}

\section{A. Kesimpulan}

Penelitian tentang hubungan personal branding perupa dengan artist merchandise dalam proses berkarya menghasilkan kesimpulan bahwa, seniman mulai sadar bahwa personal branding itu penting. Karena ciri khas karya terlebih lagi ciri khas dari seorang perupa adalah nilai plus untuk menunjang eksistensinya Keaktifan seniman dalam berkarya dan berpameran adalah hal yang sangat perlu ditingkatkan oleh semua seniman untuk menunjang personal brandingnya. personal branding adalah identitas pribadi seseorang yang mampu menciptakan respon emosional terhadap orang lain mengenai kualitas dan nilai yang dimiliki oleh orang tersebut.

Seniman adalah profesi yang digandrungi banyak orang saat ini, khususnya anak muda. Tidak hanya sebagai profesi alternatif, profesi seniman ternyata adalah hal yang menjanjikan terlebih untuk mencari uang. Menjadi seorang seniman juga harus memiliki rasa profesionalisme. Seorang seniman yang memiliki jiwa profesiomalisme senantiasa mendorong dirinya untuk mewujudkan hasil kerja dan karya yang profesional. Selain sebagai pekerjaan, seni juga sebagai media ekspesi diri untuk mengembangkan apa yang sudah ada di dalam dirinya sendiri.

Seniman harus mempunyai strategi untuk mempertahankan profesionalitas. Semakin nama seorang seniman itu dikenal dan mendapatkan tempat di masyarakat, publik akan terus mempertanyakan, menunggu, menantikan yang kita lakukan berikutnya. Seperti halnya Ronald Apriyan yang sudah memikirkan karyanya untuk dua tahun ke depan. Untuk mempertahankan profesionalismenya, seniman juga harus mempertahankan 
semangat dan juga spiritnya, agar ide yang dihasilkan pada karya-karyanya segar dan mendapatkan hasil yang maksimal.

Seniman juga mempunyai jenjang karir. Seniman saat ini menggunakan tata cara ilmu branding untuk melakukan marketing pada dirinya sendiri. Strategi marketing karya seni dapat diadaptasi dari strategi pemasaran sebuah brand dengan menjadikan seniman itu sendiri sebagai brand. Reputasi seniman akhirnya juga mempengaruhi proses berkesenian. Semakin tinggi reputasi seorang Seniman yang aktif berkarya membutuhkan apresiasi, oleh karenanya eksistensi seniman juga menjadi hal pokok dalam menunjang personal branding. Eksistensi adalah modal utama seniman dalam menghadapi segala kemungkinan yang terjadi dalam kehidupan ini khususnya didunia kerja, karena di dalam dunia kerja keberadaan sosial sangat dibutuhkan untuk meningkatkan status sosial dan meningkatkan penghasilan.

Seniman memperluas eksistensinya, yaitu dengan media sosial. Dengan adanya pembuktian keberadaannya di dunia maya atau media sosial, maka jangkauan eksistensinya di dunia nyata juga akan lebih luas. Di dalam media sosial pun, seniman dapat dengan mudah mendapatkan link selain dengan berpameran dan mengadakan kegiatan berkesenian. Untuk itu, penataan feeds dan unggahan foto serta video di Instagram harus dipikirkan matang-matang agar pengunjung ataupun penggemar menjadi tertarik untuk menikmati hasil unggahan tersebut. Seperti penyajian data pada diagram like dan comment, dapat dilihat bahwa seiring bertambahnya tahun dan keaktifan seniman dalam mengelola Instagramnya, eksistensinya semakin meningkat. Media sosial untuk senimanjuga dijadikan sebagai media untuk membangun identitas diri seniman. Dari diagram ketiga akun Instagram pada penyajian data, disimpulkan bahwa personal branding dilakukan dengan sangat baik dan hasilnya signifikan. Dapat dilihat bahwa dengan berjalannya waktu, penggemar di media sosial semakin meningkat dan seniman lebih banyak dikenal, sehingga penjualan artist merchandise dan juga relasi yang datang semakin banyak.

Dari hasil wawancara dalam penelitian ini, juga didapatkan temuan baru bahwa Ronald Apriyan melakukan beberapa cara baru dalam proses berkaryanya, dengan membaca isu-isu yang ada untuk membuat karyanya. Ronald bahkan sudah membuat karya lukisnya dua tahun sebelum karya itu diluncurkan. Saat diluncurkan pun, karyanya selalu mendapatkan apresiasi yang luar biasa. Sehingga Ronald seperti tidak mempunyai batasan dalam mengeksekusi ide-idenya menjadi sebuah karya.

Artist merchandise saat ini, juga menjadi salah satu media seniman dalam menunjang eksistensi dan juga personal branding. Artist merchandise dipilih seniman sebagai media promosi karya dan membangun image karya mereka. Tujuan membuat artist merchandise karena ingin penggemar yang tidak mampu membeli karya orisinil mereka atau yang disebut juga penggemar "low budget", dapat membeli karyanya dalam bentuk yang lebih terjangkau dan medianya juga lebih bermacam-macam. Seniman ingin melihat karya mereka di media apapun. Seorang seniman yang memutuskan untuk membuat karyanya dalam bentuk artist merchandise juga sudah harus mempunyai pengelolaan yang baik. Seperti halnya Rara, Tempa memang sejak awal sudah membuat artist merchandise sebagai media berkaryanya, sehingga pengelolaan artist merchandisenya sudah sangat siap dan baik. Berbeda dengan Ronald yang lebih memilih berkolaborasi dengan seniman dan brand lain karena dianggapnya lebih simple dan efisien. seniman, maka kepercayaan penggemar maupun kolektor akan semakin besar.

Ronald dan Rara sebenarnya adalah generasi baru yang membuat artist merchandise, karena sudah dilakukan oleh seniman-seniman dan komunitas terdahulu seperti Eddie Hara, Eko Nugroho, dan kolektif Taring Padi.

Karya dan artist merchandise tidak 
$100 \%$ berhubungan langsung. Karena keduanya berdiri pada publiknya masingmasing. Tetapi apabila karya menjadi inspirasi untuk publik mengambangkan selera mengkoleksi artist merchandise, itu lebih sering terjadi, kaitannya dengan penggemar yang kurang mampu membeli karya orisinil. Jumlah pameran yang terjadi karena penjualan artist merchandise juga dapat meningkatkan ajakan pameran dengan tingkat pameran nasional sampai internasional.

Ronald Apriyan dan Rara Kuastra mempunyai Roll Model untuk menunjang hasil karya seninya seperti salah satu seniman idola yang sama, yaitu Takashi Murakami. Mereka menjadikan Takashi Murakami sebagai Roll Model dan menjadi referensi mereka untuk berkarya, dengan catatan mereka tidak memplagiat karya Murakami, hanya menjadikan Murakami sebagai motivasi mereka dalam berkarya. Hal ini menjadi salah satu temuan terbaru karena beberapa seniman sadar bahwa dalam proses berkarya, mereka tidak dapat menciptakan karya yang benar-benar orisinil dari pemikiran mereka. Karya yang mereka buat sedikit banyak pasti terinspirasi dari karya-karya yang telah mereka lihat sebelumnya.

Proses pengumpulan data melalui wawancara sangat efektif untuk mengetahui fakta-fakta yang sebenarnya terjadi saat ini, sehingga penulis tidak banyak menelaah apa yang akan disajikan dalam penelitian. Dalam proses pengumpulan data wawancara ini juga menjadi hal yang baik, karena didapatkan beberapa temuantemuan baru yang belum banyak dibahas oleh peneliti sebelumnya. Selain itu, pengumpulan data melalui observasi media sosial seniman, juga sebagai suatu cara untuk mengetahui aktivitas yang dilakukan seniman sehari-hari seperti pameran, kolaborasi, dan kegiatan berkesenian lainnya.

Kendala yang dialami penulis dalam proses wawancara adalah minimnya waktu untuk bertemu dengan narasumber, karena narasumber yang diteliti mempunyai agenda berkarya yang sangat padat.

\section{B. Saran}

Hasil penelitian ini diharap dapat mengispirasi seniman rupa lain untuk dapat memanfaatkan personal brandingnya agar masyarakat bisa lebih mengenal dan lebih mudah mendapatkan apresiasi. Seniman rupa juga diharap dapat memanfaatkan artist merchandise dan media sosial Instagram sebagai media untuk membangun ciri khas dan citra diri mereka. Serta, menjadikan media tersebut untuk bertemu dengan lebih banyak link.

Karya artist merchandise dan juga personal branding seniman rupa sangat menarik untuk dibahas lebih lanjut dan menjadi peluang besar bagi peneliti selanjutnya, serta dapat dielaborasi lebih lanjut.

\section{DAFTAR PUSTAKA}

Aaker, David. 2015. Aaker On Branding. Jakarta: PT Gramedia Pustaka Utama.

Alditio, Iqbal. 2016. Jurnal Tugas Akhir: Perancangan Video Blog Studis TV Sebagai Media Alternatif Informasi Fakultas Seni Rupa Institut Seni Indonesia Yogyakarta.Yogyakarta: ISI Yogyakarta.

Anindita, Gisela. 2018. Strategi Portofolio Unit Bisnis Seniman (Sudi Kasus Yayasan dan CV Eko Nugroho. Yogyakarta: Pascasarjana ISI Yogyakarta.

Bahari, Nooryan. 2008. Kritik Seni "Wacana, Apresiasi dan Kreasi". Yogyakarta: Pustaka Pelajar.

Bastomi, Suwaji. 1992. Wawasan Seni. Semarang: IKIP Semarang Press.

Butar, Christhoper Rafael Butar dan Dini Salmiyah Fithrah Al. 2018. Strategi Personal Branding Selebgram Non Selebriti. Bandung: Universitas Telkom.

Dewi, Ike Janita. 2009. Creating \& Sustaining Brand Equit. Yogyakarta: Asmara Books.

Fitriyani, Nurul Laila. 2017. Perancangan Promosi Brand Handmade "Hipme" Melalui Media Instagram Sebagai 
Upaya Meningkatkan Brand Image. Yogyakarta: ISI Yogyakarta.

Hadi, Sutrisno. 1984. Metodologi Research.

I. Yogyakarta: Fakultas Psikologi Universitas Gajah Mada.

Junaedi, Deni. 2017. Estetika : Jalinan Subjek, Objek, dan Nilai. Yogyakarta: ArtCiv.

Maghfiroh, Mirrah Fitriana. 2017. Aplikasi Instagram Dalam Meningkatkan Eksistensi Eko Nugroho. Yogyakarta: ISI Yogyakarta.

Marianto, M. Dwi, Terjemahan : ARTTALK (Rosalind Ragans, Ph. D., Glencoe, Mc Graw-Hill-2005), (Yogyakarta: UPT Perpustakaan ISI Yogyakarta, 2010).

Nawawi, Handari. 1995. Metode Penelitian Bidang Sosial. Yogyakarta: Gajah Mada University Press.

Pranendra, Rama. 2016. Perancangan Merchandise Sarasvati Sebagai Pendukung Visual Branding Kampus Institut Seni Indonesia Yogyakarta. Yogyakarta: ISI Yogyakarta.

Ragans, Rosalind. 2005. ARTTALK. Alih

Bahasa: M. Dwi Marianto.

Yogyakarta: UPT Perpustakaan ISI

Yogyakarta.

Ratna, Nyoman Kutha. 2010. Metodologi Penelitian Kajian Budaya dan Ilmu Sosial Humaniora pada Umumnya. Yogyakarta: Pustaka Pelajar.

Santo, Tris Neddy, dkk. 2012. Menjadi Seniman Rupa. Solo: PT Tiga Serangkai Pustaka Mandiri.

Satori, Dja'man dan Aan Komariah. 2009. Metodologi Penelitian Kualitatif. Bandung: Alfabeta.

Sugiyono. 2012. Metode Penelitian Kuantitatif dan Kualitatif. Bandung: Alfabeta

Swasty, Wirania. 2016. Branding: Memahami dan Merancang Strategi Merek. Bandung: PT Remaja Rosdakarya.

Tamimy, Muhamad Fadhol. 2017. Sharing-mu Personal Branding-mu. Jakarta: Visimedia.

\section{Sumber Internet :}

https://gagosian.com/

https://insitu.id/

https://kbbi.web.id/

https://kopikeliling.com/

https://m.harianjogja.com/

https://rehartanto.art/2018/

https://qubicle.id/

https://www.academia.edu/

https://www.artnet.com/

https://www.artsy.net/collection/

https://www.dictio.id/

https://www.dgtmb.wordpress.com/ https://www.lifestyle.kompas.com/ https://www.mldspot.com/ 